\title{
Effects of the Share Remuneration System on Fisheries Management Targets and Rent Distribution
}

\author{
Guillen Jordi ${ }^{1,2}$, Macher Claire ${ }^{1}$, Merzereaud Mathieu ${ }^{1}$, Boncoeur Jean ${ }^{3}$, Guyader Olivier ${ }^{1}$ \\ ${ }^{1}$ IFREMER, UMR AMURE, Unite Econ Maritime, F-29280 Plouzane, France. \\ ${ }^{2}$ CSIC, Inst Ciencies Mar, E-08003 Barcelona, Spain. \\ ${ }^{3}$ Univ Brest, UMR AMURE, IUEM, F-29238 Brest 3, France.
}

Corresponding authors : email addresses : jordiguillen@hotmail.com ; claire.macher@ifremer.fr ; mathieu.merzereaud@ifremer.fr ; jean.boncoeur@univ-brest.fr ; olivier.guyader@ifremer.fr

\begin{abstract}
:
Most fisheries worldwide remunerate their crew with a share system, where crew receive a part of the revenues or a part of the revenues less costs, rather than a fixed wage. Although labor is one of the main costs in fisheries and the share remuneration system has a strong influence on firm behavior and its economic performance, little attention has been paid it. In a share remuneration system, crew salaries can significantly increase when the economic performance of a vessel improves. This allows the crew to capture part of the fisheries rent. Bioeconomic analyses are performed for the Bay of Biscay nephrops fishery on main management targets. Results confirm the importance of considering a share system compared to a fixed remuneration system in vessel owner (capital) and crew (labor) rent distribution and fishing decisions.
\end{abstract}

Keywords: Remuneration systems, share remuneration, lay system, MSY, MEY, open access, bioeconomic modeling, nephrops

JEL Codes : Q22, J33, M52. 


\section{Introduction}

Most fisheries worldwide have traditionally used and continue to use a share (or lay) system to remunerate crew (Zoeteweij 1956; Sutinen 1979; Anderson 1982; Platteau and Nugent 1992; Matthiasson 1997; McConnell and Price 2006; Christensen 2010; Vestergaard 2010). In such a remuneration system, the vessel crew is paid with a share of the vessele ${ }^{\text {ee }}$ revenues or a share of the vesseles revenues minus costs, rather than a fixed wage. There are important variations in the share remuneration systems used worldwide, one of the major differences being the degree to which the crew pays the variable costs (Zoeteweij 1956).

There are several reasons why the share remuneration system is used in fisheries. It has proven to enhance productivity in a significant way (Weitzman and Kruse 1990). This is because share wages help to share risks between the crew and vessel owner (Stiglitz 1974; Sutinen 1979; Plourde and Smith 1989), but more importantly, thus solve the principal-agent problem (Eisenhardt 1989; Vestergaard 2010) by providing incentives based on outputs in situations where monitoring of workeres effort is unobservable or costly (Stiglitz 1974; McConnell and Price 2006). The share remuneration system also enables the crew to capture part of the fisheries rent (Griffin, Lacewell, and Nichols 1976). This has implications for the attractiveness of the sector on the labor market, for an activity where the required strenuous work onboard limits the labor supply.

Labor costs have a significant impact on fishing costs and consequently on the economic performance and strategies. Jin et al. (2002) calculate that labor costs represent 30 to $60 \%$ of total costs (including fixed costs) in the New England groundfish fleet. Labor costs represent about $35 \%$ on average of the total EU fishing fleet costs (STECF 2012). Daurès, Trenkel, and Guyader (2013) estimated that labor costs represent between 40 and $60 \%$ of total costs of the French fleets operating in the Atlantic area (Bay of Biscay) depending on the fleets considered, with highest percentages for vessel using passive gear.

The distinction between remuneration of labor and remuneration of invested capital is not systematic for many units, especially for those in which the owner is also the fisher onboard (Boncoeur et al. 2000) which is the case for most small-scale fleets in Europe (Guyader et al. 2013) and worldwide (Thuy, Flaaten, and Anh 2013). 
Despite the importance of share remuneration system on fisheries firm behavior and rent distribution between owner and crew, it has received little attention. Most economic and bioeconomic analyses of fisheries have been conducted considering linear total costs proportional to fishing effort; hence, crew costs proportional to effort and constant crew wages (Gordon 1954; Clark 1990; Bjorndal, Ussif, and Sumaila 2004). Even when shared crew wages have been properly modeled (Lleonart et al. 2003; Maynou et al. 2006; Macher et al. 2008; Raveau et al. 2012), the consequences of this remuneration system have often been overlooked.

In the classic Gordon-Schaefer model all economic rents are captured by the vessel owner (Gordon 1953, 1954; Schaefer 1954, 1957). But under a share remuneration system crew salaries can increase when economic performance increases, and consequently the crew captures part of the fisheries rent. Economic rents are no more equal to profits under a share remuneration system. Therefore, it is not valid that the maximum economic yield (MEY) management objective is equivalent to maximum profits (Dichmont et al. 2010).

The bioeconomic model IAM (Impact Assessment Model for fisheries management) is used in this study to estimate the outcomes of the main management objectives (i.e., maximum sustainable yield (MSY), MEY, maximum sustainable profits, and maximum employment). The IAM model is an integrated, age-structured model coupling the biological dynamics of fish stocks with the economic dynamics to perform impact assessments taking into account the biological and economic impacts for fleets. The model was used in Macher et al. (2008) and Raveau et al. (2012) to assess the impact of selectivity improvements in the nephrops fishery of the Bay of Biscay. It was also used in 2011 within the Scientific, Technical and Economic Committee for Fisheries (STECF) to assess several scenarios of achieving MSY in the sole fishery of the Bay of Biscay (STECF 2011) and in Guillen et al. (2014) to estimate MSY in the presence of discards, while Guillen et al. (2013) estimated MSY and MEY in multi-species and multi-fleet fisheries.

Thus, this study explores the effects on crew wages and fisheries rent distribution between owner and crew of the share remuneration system compared to the fixed wage 
remuneration system by estimating several management targets (MSY, maximum sustainable rent, maximum sustainable profits, and maximum employment). Analyses are applied to the Bay of Biscay nephrops (Norway lobster, Nephrops norvegicus) French fishery.

\section{Data}

In the Bay of Biscay, nephrops is fished by bottom trawlers, together with a number of other demersal species that are landed or discarded (figure 1). The fishery is managed by TACs, quotas, and a license system. In 2010, more than 170 bottom trawlers were involved in the nephrops French fishery generating more than 50 million Euros of turnover, with $63 \%$ provided by nephrops landings. Among these vessels, more than 100 bottom trawlers target nephrops throughout the year and depend on them for more than $40 \%$ of their gross revenue, while the others target nephrops only during a certain period of the year. The total crew in the fishery was 515 , with a mean crew number of 3 people per boat (table 1). ${ }^{1}$

Fleet economic and transversal data of effort and production by vessel are from the French Research Institute for the Exploitation of the Sea (IFREMER) Fisheries Information System collected notably within the Data Collection Framework (DCF) regulation (EC 2001; Van Iseghem et al. 2011). In this study, individual vessel data is aggregated at the fleet level, consequently vessels behave as homogenous. Detailed analysis of the cost structure in the Bay of Biscay fisheries can be found in Daurès, Trenkel, and Guyader (2013).

The IAM model was parameterized with the outputs (i.e., fishing mortality, stock numbers at age, mean weight at age, discards at age) from the stock assessment for the stock of nephrops in the Bay of Biscay performed by the International Council for the Exploration of the Sea (ICES 2010). A Hockey-stick stock-recruitment relationship was adjusted based on 1987-2009 data. $^{2}$

Table 2 presents the total biomass, fishing mortality, nephrops catches, landings, and discards of the bottom trawl fleet nephrops fishery in 2009. 
Table 3 details the total biomass, mean weight of biomass, fishing mortality, natural mortality, percentage of discards, mean weight of landings, and mean weight of discards of the bottom trawl fleet by nephrops age-class.

\section{Methodology}

Main equations of the IAM model relevant to the current study are described below. The IAM bioeconomic model allows to account for multi-species and multi-fleets, but in this study it modeled one species (nephrops) and one fleet (bottom trawler).

The IAM model assumes proportionality between fishing mortality of age group i $\left(F_{i}\right)$ (fishing mortality corresponding to catches) and nominal fishing effort $(E)$ :

$$
F_{i}=q_{i} \times E,
$$

where $q_{i}$ is the catchability by age-class (i) for a given fleet, and $E$ is the nominal fishing effort used.

Effort adjustments (increases or decreases) by fleet are done through the number of vessels that participate in the fishery. Fishing days by vessel and season are assumed to be constant for this analysis. Thus, variations of effort simulated in this study correspond to capacity adjustments (number of vessels).

Catches in number per age group $\left(C n_{i}\right)$ are related to fishing mortality, population abundance (number of individuals, $N_{i}$ ), and mortality by the Baranov equation:

$$
C n_{i}=F_{i} \times N_{i} \times \frac{\left(1-e^{-Z_{i}}\right)}{Z_{i}},
$$

where $Z_{i}$ is the total mortality, compounded by fishing mortality and natural mortality.

Landings in number by age-class $\left(L n_{i}\right)$ are obtained by the difference between catches in number by age-class $\left(C n_{i}\right)$ and discards in number by age-class $\left(D n_{i}\right)$ in the model and are given by:

$$
L n_{i}=C n_{i}-D n_{i}
$$


A constant discarding behavior is assumed based on historical data, so the percentage of discards in number by age $\left(d_{i}\right)$ is considered constant over time (each year). Discards in number by age-class are then estimated in the model by:

$$
D n_{i}=C n_{i} \times d_{i},
$$

Landings in weight by age-class $\left(L_{i}\right)$ are obtained by multiplying the landings in number by the mean weight of landings by age-class $\left(w_{L i}\right)$ :

$$
L_{i}=w_{L i} \times L n_{i}
$$

Total revenues (gross value of landings) are obtained from the revenue of the modeled species ( $n$ for nephrops) and the revenue from other species (oths) that are assumed to be proportional to the nephrops landings:

$$
G V L=\left(P_{n} \times L_{n}\right)+G V L o t h s,
$$

where $P$ is the price by species, $L$ is the weight of landings by species and fleet, and $G V L$ is the gross value of landings.

The gross value added (GVA) measures the fishery ${ }^{\text {ee }}$ contribution to the economy:

$$
G V A=G V L-\text { fuec }- \text { ovc }- \text { rep }- \text { fixc },
$$

where $G V L$ is the gross value of landings, fuec is fuel costs, ovc is other variable costs, rep is repair and maintenance costs, and fixc is fixed costs. This costs classification follows the EU's Data Collection Framework (EC 2008) and the Annual Economic Report of the UE fishing fleets (STECF 2012 and previous years).

Costs (variable and fixed, with the exception of salaries in the share remuneration system) are assumed here to be proportional to the number of vessels in the fleet (i.e., to the fishing effort). Crew size per vessel is assumed to remain constant.

Net profits (or owners se surplus), which is a valid proxy of the total vessel owners ${ }^{\text {ee }}$ rents, is estimated as:

$$
N P=N V L-f u e c-c c w-o v c-r e p-f i x c-d e p-o c k,
$$

where $N V L$ is the net value of landings, $c c w$ is crew costs, dep is depreciation costs, and ock is the opportunity cost of capital. ${ }^{3}$ 
The net value of landings is equal to the gross value of landings minus selling costs (ccom). The selling costs amount to about $6 \%$ of the gross value of landings and are paid at the first-sale:

$$
N V L=G V L-c c o m,
$$

Crew costs are composed of wages and social security costs. They are estimated assuming both a fixed and a share remuneration system.

- In the fixed remuneration system, wages are constant. Wages are assumed to remain constant at the status quo level. Crew wages reported in this study (as the ones reported in table 1) are gross wages and include social security and other taxes. Net crew wages correspond to about half of the gross wages. The crew costs in a fixed remuneration system $\left(\mathrm{ccw}_{f}\right)$ are equal to total crew remuneration and are obtained from multiplying the average wage (wage $)$ by the total crew number (crew):

$$
c c w_{F}=\text { wage }_{F} \times c r e w,
$$

- In a share remuneration system, crew is paid with a percentage of the revenues or the revenues minus costs. In most French fisheries, and in this nephrops fishery in particular, crew obtain a share of the difference between the total value of landings and operating costs. Then crew costs in a shared remuneration system $\left(\mathrm{ccw}_{s}\right)$ are equal to the total crew remuneration and are obtained from:

$$
c c w_{S}=\text { share_rate } \cdot(N V L-f u e c-o v c),
$$

where share_rate is the fixed proportion of revenues minus operating costs the crew receives. For the analysis it is assumed that the share rate remains constant; however, this assumption is relaxed in the discussion. Then the average crew wage in a shared remuneration system (wage s $_{s}$ is equal to the total crew remuneration (crew costs) divided by the number of crew:

$$
\text { wage }_{S}=\frac{c c w_{S}}{c r e w}
$$

Labor rent (or crew surplus) is estimated from the difference between crew wages and the opportunity cost of labor $(o c l)$ : 


$$
L R=\text { wage }- \text { ocl, }
$$

The opportunity cost of labor is initially considered to be equal to the constant wages; however, this assumption is later discussed.

In most small-scale fisheries, as well as in this fishery, most of the vessel owners are also skippers. In this analysis it is assumed that all vessel owners work on the vessel, and it is the owner who makes the fishing decisions in order to maximize profits.

Simulations on the evolution of main indicators for the nephrops fishery according to a range of effort multipliers were performed with the IAM model. MSY, maximum sustainable rents, maximum sustainable profits, and maximum employment estimates at equilibrium were obtained by optimization with the IAM model.

This study compares sustainable management targets, and, therefore, fisheries are analyzed at equilibrium. Sustainable fisheries, or fisheries at equilibrium, imply that nephrops mortality by fishing is equal to the nephrops stock growth. For each effort level, and therefore fishing mortality, there is a sustainable stock size. If current stock size was lower than the sustainable level, there should be a transition period where fishing effort and quotas need to be reduced with the aim to recover the stock at a sustainable level. On the other hand, if the stock size is higher than the sustainable stock level, there would be the need to set quotas higher so that the stock biomass could reduce to its sustainable level. Nephrops stock is currently overfished and a transition period is needed to let the biomass grow to a sustainable level (ICES 2010; Guillen et al. 2013).

Therefore, the status quo level used in this study represents the current fishing effort (number of vessels and fishing days) taking place at the sustainable stock level. The maximum employment management target is defined following Pilling et al. (2008) as the maximum effort, and consequently employment, in a non-loss fishery. Thus, maximum employment corresponds to the open-access point where the fishery generates no profit. Open access is based on the condition that access to a fishery is unrestricted. 
The net profits (owners ${ }^{e e}$ rent) and labor rent are estimated for the following management targets:

A. Maximization of sustainable fisheries rent (labor + owners rent),

B. Maximization of sustainable profits,

C. MSY: maximization of landings in weight,

D. Status quo: assuming that current fishing effort remains constant,

E. Maximum employment or open access: It corresponds to the level of 0 profits and maximum effort, and consequently employment, that the fishery could sustain.

\section{Results}

Estimations of the different management targets at equilibrium, assuming fixed and share remunerations, were obtained by optimization with the IAM model. Main results are presented in table 4 and figure 2.

From table 4 and figure 2, it can be seen that the fishing effort levels required to achieve most management targets do not change significantly when accounting for share or fixed salaries. The fishing effort that maximizes profits (B) for fixed and share salaries is the same as that needed to maximize rents (A) for fixed salaries; only the effort needed to maximize rents for shared salaries is higher (fishing effort multiplier of 0.33 compared to 0.30). Management target $\mathrm{C}$ (maximum landings) refers to a fully biological objective; therefore, the effort needed to achieve it is not affected by whether salaries are share or fixed. Also, effort at the status quo situation (point D) is the same by definition (effort multiplier equal to 1) for both remuneration types. Moreover, notice that the status quo point (D) is close to open-access point (E), where the effort multiplier at open access is 1.04 when assuming constant wages and 1.05 when assuming shared wages. On the other hand, there are significant differences between average wages and rent distribution when accounting for share or fixed salaries.

Results presented in table 4 show that crew salaries, assuming a share system, vary (and especially increase) significantly when other management targets are aimed: 209,081€ when maximizing rents, $187.903 €$ when maximizing profits, 97,001 $€$ when maximizing landings, and $46,246 €$ in open access. Constant salaries are equal to the status quo salaries $(49,801 €)$. Salaries continue to decrease when effort increases 
beyond open access. Crew salaries in the share remuneration system could decrease below the minimum wage. These estimations are calculated assuming that there is no uncertainty (i.e., inter-annual variations in recruitment). ${ }^{4}$

These high salaries lead to a higher importance of the salaries in the total fishing costs (almost 79\% when maximizing fisheries rent). Consequently, the firm ses profits (or owner surplus) are lower with a share remuneration than with a constant wage system (see table 4 and figure 2). Profits for share remuneration compared to the fixed remuneration were 52\% lower for profit maximization, 51\% lower for rent maximization objectives, and 48\% lower when maximizing landings (MSY).

Fishing costs that are commonly represented by a straight line proportional to effort become a concave curve when the share remuneration system is considered (see Total costs $f$ and Total costs $s$ in figure 2). The economic rent captured by the vessel owners (owner surplus) in a constant wage remuneration system is equivalent to the distance between the curve of total landings value ${ }^{5}$ and the total cost line when assuming a fixed remuneration system (the rent is equal to the sum of the light grey and dark grey distances at each effort level in figure 2). In a shared remuneration system, the economic rent captured by the vessel owners (light grey color) is defined by the distance between the total value of landings and the cost curve "Total costs s". While the difference between the total costs curve "Total costs s" and the "Total costs $\mathrm{f}$ " line (which accounts for the opportunity cost of labor) is the economic rent captured by the crew (dark grey color).

When landings (in weight) are maximized (MSY), the landings value is not maximized because lower fishing effort leads to higher average weight (by individual) of landings, and consequently a higher price per kg (Guillen et al. 2014).

\section{Discussion}

In overfished and overcapitalized fisheries, such as this nephrops fishery, it is commonly advised to reduce effort in order to increase the long-term yields and economic performance of the fleets (Worm et al. 2009; FAO 2012). Current fishing effort needs to be reduced by 67 to $70 \%$ to maximize profits or rents and $38 \%$ to maximize landings in this fishery, as detailed in table 4 and figure 2. These 
recommended reductions are in line with Guillen et al. (2013) who estimated effort to be reduced between 61 and $78 \%$ to maximize profits and 34\% to maximize landings.

However, the expected long-term economic benefits for the vessel owners of these effort reductions are not so significant when accounting for a shared remuneration system. Indeed, results for the nephrops Bay of Biscay fishery show that the differences between profits when maximized and at status quo are 21.2 M€ (23.1 M€ compared to 1.8 $\mathrm{M} €$ ) for shared and 45.3 $\mathrm{M} €$ (47.2 $\mathrm{M} €$ compared to 1.8 $\mathrm{M} €$ ) for fixed remuneration systems. While the profit differences between MSY and at status quo are 14.6 M€ for shared and 29.7 M€ for fixed remuneration systems.

Therefore, mid- to long-term returns to remaining vessel owners could be overestimated if a fixed remuneration system is wrongly assumed. This could be of extreme importance when estimating the net present value of the effects of a management measure. In particular, because most measures to rebuild fish stocks deteriorate the short term economic performance that should be compensated with a better economic performance at a later stage (i.e., selectivity improvements as shown in Macher et al. 2008; Lleonart et al. 2003; OECD 2012). Thus, this long-term profitability overestimation can easily lead to recovering the investment at a later stage than the estimated one, if at all. This lower net present value of the effects of a management measure could be worsened by a lower price increase than expected when initially reducing landings as reported by Nielsen, Smit, and Guillen (2012).

This happens because in a share remuneration system rents, and thus risks, are shared between the vessel owner and crew. When the economic performance of a fleet increases, the crew is able to capture some of the fishery rents due to wage increases. Therefore, in a share remuneration system, fishery rents are split between owners ${ }^{\text {ee }}$ rents (profits) and labor rents. Distribution of rents depends on the share rate between the owner and crew. However, it should be noted that rents between crew and owner are not proportionally shared. This is because when splitting "rents," the calculation is not based solely on the rent (i.e., landings value minus all costs) but often only operational costs are subtracted from the value of landings before the split. Indeed, labor rents are calculated by subtracting the labor opportunity costs to the crew share of the amount left after subtracting the operational costs from the value of landings. While owners ee rents 
are calculated by subtracting repair and maintenance, fixed costs, depreciation, and capital opportunity costs to the owner share of the amount left after subtracting the operational costs from the value of landings. Thus, the vessel owner has to bear the fixed and capital costs alone.

This implies that under a share remuneration system it could be possible that labor rent is maximized for an effort level different from the one that maximizes profits. Indeed, as can be seen in table 4 and figure 2, the fishing effort that maximizes profits (B) and rents (A) for fixed salaries is the same, as in the classic Gordon-Schaefer model; while the effort that maximizes rents (A) is higher than the one that maximizes profits (B) for shared salaries. MEY refers to the sustainable harvest level that generates the largest total surplus (economic rent) in the fishery, and consequently, equals management target A (rent maximization). However, the MEY management target has often been treated as equivalent to maximize profits (Dichmont et al. 2010), a simplification that does not consider that a significant part of fisheries rents can be captured by crew salaries under share remuneration systems.

Similarly, in open access (when employment is maximized under the condition that profits and thus owner rents are zero) labor rent could be different from 0; either positive or negative depending on the remuneration system. The different effort levels at which open access and zero labor rents exist depend on the relation between fixed and capital costs and the opportunity cost of labor. However, if labor rent becomes negative before reaching open access (wages under a share remuneration system are below the fixed remuneration rate), the crew would be paid less than the opportunity cost of labor. If vessel owners are not willing to pay higher salaries (i.e., change the share rate or fixed wages), then they would have difficulties finding labor because crew could decide to switch jobs. This may eventually restrict fishing effort to the point where labor rent is zero instead of where overall profits are zero (open access point). Instead, it may be possible that when open access is reached, the crew is still capturing labor rents, as happened in our analysis. In that case, and in the existence of absent vessel owners, it could be possible that fishing effort increases to a point where labor rents are zero, but owners rents are negative. 
It is the vessel owner who pays for capital costs from his portion of the revenue. Other costs, such as those associated with acquiring ITQs or other fishing rights, are also normally borne by the owner. Because it is only the owner who bears the capital and investment costs in shared wage systems, Hannesson (2007) showed that it could lead to non-optimal levels of investment.

The estimation of labor rent is controversial because it is difficult to establish the real value of the opportunity cost of labor. The opportunity cost of labor refers to the wages that crew could have received from the best alternative employment elsewhere in the economy. As a result, labor rent refers to the extra wage that crew members receive for their work. The opportunity cost of labor is often assumed to be equal to the minimum salary (Guillen et al. 2013). This implies the existence of labor rent also under constant remuneration systems when the constant wage is higher than the opportunity cost of labor. In that case, labor rents would increase proportional to the number of crew; while for share remuneration systems, labor rents would present a similar pattern to that shown in figure 2.

In this study, the opportunity cost of labor is assumed to be equal to the fixed salaries. This is because it is assumed that the labor market is currently in (or near) equilibrium, and if crews receive a high wage (compared to the minimum salary), it is only because of the risks and strenuousness of their work. By assuming this, the crew is remunerated for just their labor without obtaining any labor rent.

The current common situation of overfishing and overcapacity leads to low crew salaries and consequently difficulty in finding crew. However, it is expected that if fish stocks improve and overcapacity is reduced, crew salaries will increase. Results for the Bay of Biscay nephrops fishery show that in a shared remuneration system, salaries could increase more than 4.5 times the status quo. This allows the crew to capture part of the economic rents the vessel owners would capture in a fixed remuneration system. For the Bay of Biscay nephrops fishery, when maximizing profits on a fixed wage system the owners would obtain 47.2 M€ in economic rents, while with a shared system, the owners would obtain 23.1 M€ and the crew 23.8 M€. 
Optimal fishing pressure (effort to maximize profits or rents) is affected by crew costs, which are related to the opportunity cost of labor. In a country with high levels of unemployment (e.g., many developing countries) labor is likely to be cheap because the opportunity cost of labor is very low or almost null (considering null or low entry-exit costs for employment in the fishing sector). Countries with cheap labor tend to use more labor in their production processes than countries where labor is expensive and owners tend to replace it with capital. This is one of the main factors, together with target species and fish habitat conditions, explaining the existence of different main gears and cost structures across countries. Changes in the economic performance and consequently in labor costs may have different short-term effects, depending mainly on the fishing technique used. Some fleets, such as purse seiners, appear to be more flexible when contracting work force because production is highly related to the crew size. On the other hand, in other fleets, such as trawlers, production is not as related to crew size (once the minimum operational crew size is reached), so there is little economic sense to use more crew in the production process. If these changes in the cost structure are very significant or remain in the long-term, changes in fishing techniques used should be expected.

However, for certain fisheries, as in the Bay of Biscay nephrops fishery, the number of crew employed could depend more on the amount harvested and treatment of the catch rather than labor costs. Trawlers require a certain minimum number of crew for operation, depending mainly on vessel size and gear characteristics. In periods of low catches and consequently low profitability, vessels tend to carry a crew size close to this minimum level in order to maintain salaries and economic performance. But if catches increase significantly (i.e., due to better management of the fishery) more crew would be needed to sort the harvest, independent of the remuneration system (Macher 2008). Crew size could also increase if vessels are obliged to land all catches (i.e., when a discard ban is established, as in EU fisheries), as crew will have to spend more time sorting.

Under a fixed remuneration system, if there is a change in the crew size, it implies a change in the labor costs. In a share remuneration system, when the share rate is fixed, a change in crew size would lead to changes in salaries but not on the total labor costs. 
This implies that changes in the crew size would modify owner rent in a fixed remuneration system and labor rent in a shared remuneration system.

The analyses were performed assuming a fixed share rate. However, the share rate can be used as an adjustment variable that the vessel owner can change in the presence of internal management decisions (i.e., important new investments) or in response to external shocks (i.e., fuel price increases) or management measures (i.e., introduction of ITQs (Guyader and Thebaud 2001)). It could thus be possible that once a stock starts recovering, vessel owners reduce the share of the crew portion to increase the vessel owneres share, and consequently to capture more rent once crew salaries start to increase. This could be supported by the creation of a mass of unemployed crew when effort reductions take place to achieve management objectives (for example, current effort in terms of vessels, and therefore crew, needs to be reduced by 67 to $70 \%$ as shown in table 4 and figure 2 to achieve maximum profits, assuming share and fixed remuneration systems, respectively). The existence of this unemployed crew (that could replace the current vessels ${ }^{\text {ee }}$ crew) could deter crew salaries to rise in a shared remuneration system. In this sense, share remuneration systems have proven to be selfadaptive and time-consistent, adapting to changing circumstances (Hämäläinen, Ruusunen, and Kaitala 1990; McConnell and Price 2006).

If the share rate could be continually revised to reflect equilibrium in the labor market, crew would always get the opportunity cost of their labor (Hannesson 2007), and results would be similar to those obtained assuming constant wages. If share rate was continually revised, one would expect that crew could only obtain wages higher than the current rates (i.e., equal to the opportunity cost of labor or alternative wage) when there is a skilled workforce shortage. The share system would still serve as an incentive contract to ensure that the crew exert the necessary effort to obtain a wage equal to their opportunity wage (Hannesson 2007).

However, there are also cases where the share rate has not been revised, despite significant changes in a fishery. For example, with the implementation of catch shares in the Bering Sea/Aleutian Islands crab fisheries, the share rate has remained practically unchanged, leading to substantial increases in the remuneration for many crew (Abbott, Garber-Yonts, and Wilen 2010). Therefore, whether a remuneration system is fixed or 
shared, the possibility for the crew to capture part of the vessel owners ${ }^{\text {ee }}$ rent depends on the fixity of the share rate.

\section{Conclusions}

In most fisheries worldwide, crew are remunerated through a shared remuneration system rather than a fixed wage. In a share remuneration system, crew receive part of the revenues or part of the revenues less costs. So, in a share remuneration system, crew salaries can significantly increase when the economic performance of a fleet improves (i.e., due to stock recovery), allowing the crew to capture a portion of the fisheries rent. Therefore, under a share remuneration system, economic rents are not equal to profits. Consequently, the rent maximization (MEY) management target is not equivalent to the profit maximization management target under share remuneration systems. Moreover, because vessel owners do not capture all fishery rents, net present value estimations of management measures (i.e., selectivity improvements) could be overestimated.

\section{References}

Abbott, J. K., B. Garber-Yonts, and J. E. Wilen. 2010. "Employment and Remuneration Effects of IFQs in the Bering Sea/Aleutian Islands Crab Fisheries.” Marine Resource Economics 25(4):333-54.

Anderson, L. G. 1982. “The Share System in Open-Access and Optimally Regulated Fisheries." Land Economics 58:435-49.

Bjorndal, T., A.-A. Ussif, and U. R. Sumaila. 2004. "A Bioeconomic Analysis of the Norwegian Spring Spawning Herring (NSSH) Stock." Marine Resource Economics $19: 353-65$.

Boncoeur, J., L. Coglan, B. Le Gallic, and S. Pascoe. 2000. "On the (Ir)relevance of Rates of Return Measures of Economic Performance to Small Boats." Fisheries Research 49:105-15.

Christensen, V. 2010. "MEY=MSY.” Fish and Fisheries 11:105-10.

Clark, C. W. 1990. Mathematical Bioeconomics: The Optimal Management of Renewable Resources. New York: Wiley.

Daurès, F., V. M. Trenkel, and O. Guyader. 2013. "Modelling the Fishing Costs of French Commercial Vessels in the Bay of Biscay." Fisheries Research 146:74-85. 
Dichmont, C. M., S. Pascoe, T. Kompas, A. Punt, and R. Deng. 2010. "On Implementing Maximum Economic Yield in Commercial Fisheries." Proceedings of the National Academy of Sciences 107:16-21.

EC (European Commission). 2001. Commission regulation (EC) No 1639/2001 of 25 July 2001 establishing the minimum and extended Community programmes for the collection of data in the fisheries sector and laying down detailed rules for the application of Council Regulation (EC) No 1543/2000. Official Journal of the European Communities. Luxembourg: Publications Office of the European Union.

------. 2008. Commission regulation (EC) No 665/2008 of 14 July 2008 laying down detailed rules for the application of Council Regulation (EC) No 199/2008 concerning the establishment of a Community framework for the collection, management and use of data in the fisheries sector and support for scientific advice regarding the Common Fisheries Policy. Official Journal of the European Communities. Luxembourg: Publications Office of the European Union.

Eisenhardt, K. 1989. "Agency Theory: An Assessment and Review." Academy of Management Review 14(1):57-74.

FAO (Food and Agriculture Organization of the United Nations). 2012. The State of World Fisheries and Aquaculture. Rome, Italy: FAO Fisheries and Aquaculture Department.

Gordon, H. S. 1953. "An Economic Approach to the Optimum Utilization of Fishery Resources." Journal of the Fisheries Board of Canada 10:442-47.

------ 1954. "The Economic Theory of a Common Property Resource: The Fishery." Journal of Political Economy 62:124-42.

Griffin, W. L., R. D. Lacewell, and J. P. Nichols. 1976. “Optimum Effort and Rent Distribution in the Gulf of Mexico Shrimp Fishery." American Journal of Agricultural Economics 58:644-52.

Guillen, J., C. Macher, M. Merzéréaud, M. Bertignac, S. Fifas, and O. Guyader. 2013. "Estimating MSY and MEY in Multi-species and Multi-fleet Fisheries: The Bay of Biscay Mixed Fishery." Marine Policy 40:64-74.

Guillen, J., C. Macher, M. Merzéréaud, S. Fifas, and O. Guyader. 2014. "The Effect of Discards and Survival Rate when Choosing between Landings or Catches as Yield in the Maximum Sustainable Yield Estimation: Application to the Nephrops Fishery in the Bay of Biscay". Marine Policy 50:207-14. 
Guyader, O., B. Berthou, C. Koutsikopoulos, F. Alban, S. Demaneche, M. B Gaspar, R. Eschbaum, E. Fahy, O. Tully, L. Reynal, O. Curtil, K. Frangoudes, and F. Maynou. 2013. "Small Scale Fisheries in Europe: A Comparative Analysis based on a Selection of Case Studies." Fisheries Research 140:1-13.

Guyader, O., and O. Thebaud. 2001. "Distributional Issues in the Operation of Rightsbased Fisheries Management Systems.” Marine Policy 25:103-12.

Hämäläinen, R.P., J. Ruusunen, and V. Kaitala. 1990. "Cartels and Dynamic Contracts in Share Fishing." Journal of Environmental Economics and Management 19:175-92.

Hannesson, R. 2007. "Taxes, ITQs, Investments, and Revenue Sharing." Marine Resource Economics 22:363-71.

ICES (International Council for the Exploration of the Sea). 2010. "Report of the Working Group on the Assessment of Southern Shelf Stocks of Hake, Monk and Megrim (WGHMM),” May 5 - 11, 2010, Bilbao, Spain. ICES CM 2010/ACOM:11.

Jin, D., E. Thunberg, H. Kite-Powell, and K. Blake. 2002. “Total Factor Productivity Change in the New England Groundfish Fishery: 1964-1993." Journal of Environmental Economics and Management 44:540-56.

Lleonart, J., F. Maynou, L. Recasens, and R. Franquesa. 2003. “A Bioeconomic Model for Mediterranean Fisheries, the Hake off Catalonia (Western Mediterranean) as a Case Study." In Fish Stock Assessments and Predictions: Integrating Relevant Knowledge, ed. Ø. Ulltang and G. Blom. Scientia Marina 67(Suppl. 1):337-51.

Macher, C. 2008. "Productions Jointes et Mesures de Gestion des Pêcheries Mixtes: Application à la Pêcherie Chalutière Langoustinière du Golfe de Gascogne." PhD diss., Université de Bretagne Occidentale. http://archimer.ifremer.fr/doc/00000/4857/.

Macher, C., O. Guyader, C. Talidec, and M. Bertignac. 2008. "A Cost-benefit Analysis of Improving Trawl Selectivity in the Case of Discards: The Nephrops norvegicus Fishery in the Bay of Biscay." Fisheries Research 92:76-89.

Matthiasson, T. 1997. "Fixed Wage or Share: Contingent Contract Renewal and Skipper Motivation.” Mimeo, Institute for Economic Studies, University of Iceland.

Maynou, F., F. Sardà, S. Tudela, and M. Demestre. 2006. "Management Strategies for Red Shrimp (Aristeus antennatus) Fisheries in the Catalan Sea (NW Mediterranean) based on Bioeconomic Simulation Analysis.” Aquatic Living Resources 19(2):161-71.

McConnell, K. E., and M. Price. 2006. "The Lay System in Commercial Fisheries: Origin and Implications." Journal of Environmental Economics and Management 51(3):295-307. 
Nielsen, M., J. Smit, and J. Guillen. 2012. "Price Effects of Changing Quantities Supplied at the Integrated European Fish Market." Marine Resource Economics 27(2):165-80.

OECD (Organization for Economic Cooperation and Development). 2012. "Rebuilding Fisheries: The Way Forward." http://www.oecd.org/tad/fisheries/rebuildingfisheriesthewayforward.htm

Pilling, G. M., L. T. Kell, T. Hutton, P. J. Bromley, A. N. Tidd, and L. J. Bolle. 2008. "Can Economic and Biological Management Objectives be Achieved by the Use of MSY-based Reference Points? A North Sea Plaice (Pleuronectes platessa) and Sole (Solea solea) Case Study.” ICES Journal of Marine Science 65:1069-80.

Platteau, J. P., and J. Nugent. 1992. "Share Contracts and their Rationale: Lessons from Marine Fishing.” Journal of Development Studies 28:386-422.

Plourde, C., and J. B. Smith. 1989. "Crop Sharing in the Fishery and Industry Equilibrium." Marine Resource Economics 6:179-93.

Raveau, A., C. Macher, S. Méhault, M. Merzéréaud, C. Le Grand, O. Guyader, M. Bertignac, S. Fifas, and J. Guillen. 2012. "A Bio-economic Analysis of Experimental Selective Devices in the Norway Lobster (Nephrops norvegicus) Fishery in the Bay of Biscay.” Aquatic Living Resources 25:215-29.

Schaefer, M. B. 1954. "Some Aspects of the Dynamics of Populations Important to the Management of Commercial Marine Fisheries." Inter-American Tropical Tuna Commission 1:27-56.

-----. 1957. "Some Considerations of Population Dynamics and Economics in Relation to the Management of the Commercial Marine Fisheries." Journal of the Fisheries Research Board of Canada 14(5):669-81.

STECF (Scientific, Technical and Economic Committee for Fisheries). 2012 Annual Economic Report on the EU Fishing Fleet (STECF-12-10). JRC Scientific and Technical Reports. Luxembourg: Publications Office of the European Union.

-----. 2011. Impact Assessment of Bay of Biscay Sole (STECF-11-01). JRC Scientific and Technical Reports. Luxemburg: Publications Office of the European Union.

Stiglitz, J. 1974. "Incentives and Risk Sharing in Sharecropping." Review of Economic Studies 41(2):219-56.

Sutinen, J. G. 1979. "Fishermens "e Remuneration Systems and Implications for Fisheries Development." Scottish Journal of Political Economy 26:147-62. 
Thuy, P. T. T., O. Flaaten, and N. T. K. Anh. 2013. "Remuneration Systems and Economic Performance: Theory and Vietnamese Small-scale Purse Seine Fisheries." Marine Resource Economics 28(1):19-41.

Van Iseghem, S., E. Quillerou, C. Brigaudeau, C. Macher, O. Guyader, and F. Daures. 2011. "Ensuring Representative Economic Data: Survey Data-Collection Methods in France for Implementing the Common Fisheries Policy." ICES Journal of Marine Science 68:1792-99.

Vestergaard, N. 2010. "Principal-Agent Problems in Fisheries." From the Selected Works of Niels Vestergaard. http://works.bepress.com/vestergaard/1.

Weitzman, M., and D. Kruse. 1990. "Profit Sharing and Productivity." In Paying for Productivity: a Look at the Evidence, ed. A. Blinder, 95-140. Washington, DC: Brookings Institution.

Worm, B., R. Hilborn, J. K. Baum, T. A. Branch, J. S. Collie, C. Costello, M. J. Fogarty, E. A. Fulton, J. A. Hutchings, S. Jennings, O. P. Jensen, H. K. Lotze, P. M. Mace, T. R. McClanahan, C. Minto, S. R. Palumbi, A. M. Parma, D. Ricard, A. A. Rosenberg, R. Watson, and D. Zeller. 2009. "Rebuilding global fisheries." Science 325:578-85.

Zoeteweij, H. 1956. "Fishermen's Remuneration." In The Economics of Fisheries, ed. R. Turvey and J. Wiseman. Rome, FAO. 


\section{Figures}

Figure 1. Nephrops Fishery in the Bay of Biscay

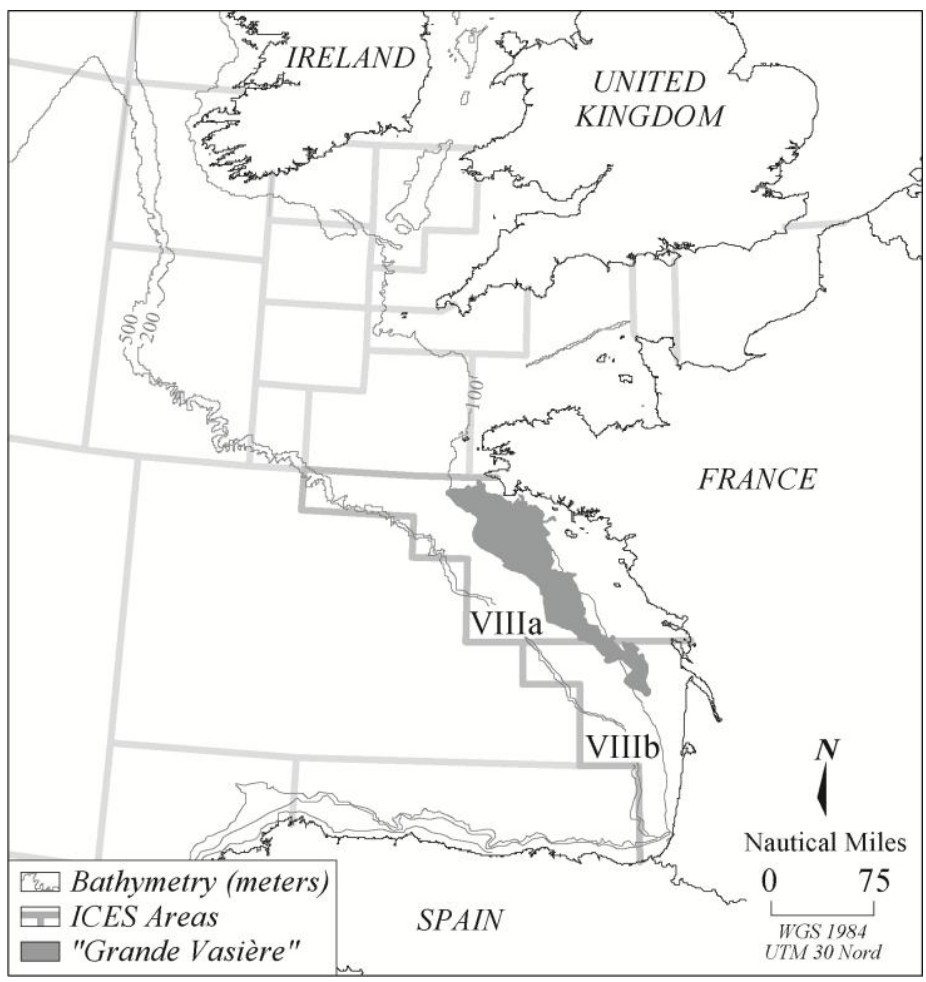


Figure 2. Management targets in equilibrium under both shared (s) and fixed (f) remuneration systems and owner and crew surplus (rents) estimation as a function of fishing effort.

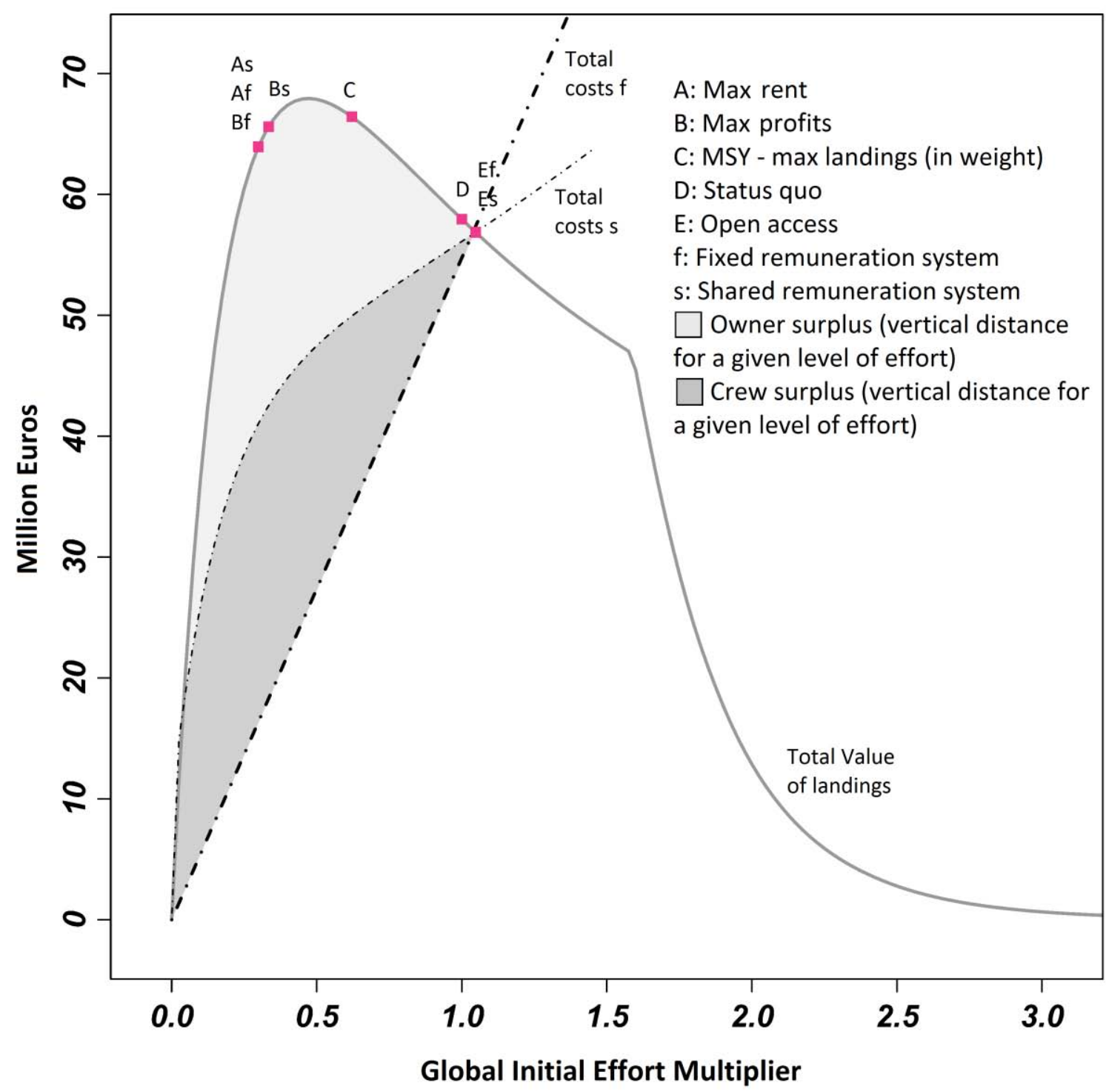

Note below figure 2

In shared remuneration systems, owner rent is defined by the distance between the total value of landings and the Total costs $s$ (light grey), and labor rent corresponds to the distance between the Total costs $s$ and the Total costs $f$ line (dark grey). In fixed remuneration systems, owner rent is equal to the distance between the total value of landings and the Total costs $f$ (light grey + dark grey). 


\section{Tables}

Table 1. Main Economic Data of the Nephrops Fishery in 2010

\begin{tabular}{lr}
\hline Number of vessels & 172 \\
Total crew & 515 \\
Value total landings $(\mathrm{M} €)$ & 54.2 \\
Value nephrops landings $(\mathrm{M} €)$ & 34.2 \\
Total costs $(\mathrm{M} €$ ) & 54.7 \\
Crew costs in total costs $(\%)$ & 44.4 \\
Average annual crew wage $(€)$ & 47,153 \\
GVA $(\mathrm{M} €$ ) & 29.9 \\
Net profits $(\mathrm{M} €)$ & -0.5 \\
\hline
\end{tabular}


Table 2. Main Data of the Nephrops Fishery in 2009

\begin{tabular}{ll}
\hline Biomass nephrops (tonnes) & 17,947 \\
Fishing mortality nephrops (F total catches) & 0.49 \\
Catches nephrops (tonnes) & 4,862 \\
Discards nephrops (tonnes) & 1,832 \\
Landings nephrops (tonnes) & 3,029 \\
\hline
\end{tabular}

Source: ICES (2010) 
Table 3. Nephrops Stock Input Data for 2010

\begin{tabular}{|c|c|c|c|c|c|c|c|}
\hline Age-class & $\begin{array}{l}\text { Stock Size } \\
(' 000 \mathrm{~N})\end{array}$ & $\begin{array}{l}\text { Mean Weight } \\
\text { of Biomass at } \\
\text { Age }(\mathrm{gr})\left(w_{B}\right)\end{array}$ & $\begin{array}{l}\text { Fishing } \\
\text { Mortality } \\
(F)\end{array}$ & $\begin{array}{l}\text { Percentage } \\
\text { of } \\
\text { Discards } \\
\text { (d) }\end{array}$ & $\begin{array}{l}\text { Mean Weight } \\
\text { of Landings } \\
\text { at Age (gr) } \\
\left(w_{L}\right)\end{array}$ & $\begin{array}{l}\text { Mean Weight } \\
\text { of Discards } \\
\text { at age }(\mathrm{gr}) \\
\left(w_{D}\right)\end{array}$ & $\begin{array}{l}\text { Natural } \\
\text { Mortality }\end{array}$ \\
\hline 1 & 658,752 & 3.53 & 0.016 & 100.0 & 0.0 & 3.33 & 0.30 \\
\hline 2 & 529,149 & 9.17 & 0.393 & 97.1 & 11.0 & 9.0 & 0.30 \\
\hline 3 & 206,379 & 16.53 & 0.577 & 49.1 & 18.0 & 14.67 & 0.25 \\
\hline 4 & 138,134 & 26.57 & 0.555 & 14.2 & 27.0 & 22.33 & 0.25 \\
\hline 5 & 65,863 & 36.37 & 0.439 & 6.0 & 36.67 & 35.0 & 0.25 \\
\hline 6 & 30,614 & 45.00 & 0.444 & 5.8 & 45.67 & 29.67 & 0.25 \\
\hline 7 & 12,612 & 56.83 & 0.403 & 1.7 & 56.67 & 44.33 & 0.25 \\
\hline 8 & 4,530 & 67.57 & 0.433 & 6.3 & 68.67 & 78.33 & 0.25 \\
\hline $9+$ & 4,262 & 85.43 & 0.427 & 1.7 & 85.33 & 101.33 & 0.25 \\
\hline
\end{tabular}

Source: ICES (2010) 
Table 4. Comparison of Fisheries Performance Indicators for Each Management Target in Equilibrium Assuming Fixed or Shared Remuneration System

\begin{tabular}{|c|c|c|c|c|c|}
\hline & A & B & $\mathrm{C}$ & $\mathrm{D}$ & $\mathrm{E}$ \\
\hline & $\begin{array}{l}\text { Max. } \\
\text { Rents }\end{array}$ & Max. Profits & $\begin{array}{l}\text { MSY } \\
\text { (landings) }\end{array}$ & $\begin{array}{l}\text { Status } \\
\text { Quo }\end{array}$ & Open Access \\
\hline \multicolumn{6}{|l|}{ Constant Wages } \\
\hline Effort multiplier & 0.302 & 0.302 & 0.621 & 1.000 & 1.040 \\
\hline Crew costs in total costs $(\%)$ & 46.8 & 46.8 & 46.8 & 46.8 & 46.8 \\
\hline Average annual crew wage $(, 000 €)$ & 49.8 & 49.8 & 49.8 & 49.8 & 49.8 \\
\hline Value total landings $(\mathrm{M} €)$ & 64.1 & 64.1 & 66.4 & 58.0 & 57.0 \\
\hline Gross value added $(\mathrm{M} €)$ & 56.7 & 56.7 & 51.3 & 33.6 & 31.7 \\
\hline Net profits $=$ owners"e rent $(\mathrm{M} €)$ & 47.2 & 47.2 & 31.6 & 1.8 & 0.0 \\
\hline Labor rent $(\mathrm{M} €)$ & 0.0 & 0.0 & 0.0 & 0.0 & 0.0 \\
\hline Owner + labor rent $(\mathrm{M} €)$ & 47.2 & 47.2 & 31.6 & 1.8 & 0.0 \\
\hline \multicolumn{6}{|l|}{ Share Wages } \\
\hline Effort multiplier & 0.302 & 0.334 & 0.621 & 1.000 & 1.048 \\
\hline Crew costs in total costs $(\%)$ & 78.7 & 76.9 & 63.2 & 46.8 & 45.0 \\
\hline Average annual crew wage $(, 000 €)$ & 209.1 & 187.9 & 97.0 & 49.8 & 46.2 \\
\hline Value total landings $(\mathrm{M} €)$ & 64.1 & 65.6 & 66.4 & 58.0 & 56.9 \\
\hline Gross value added $(\mathrm{M} €)$ & 56.7 & 57.5 & 51.3 & 33.6 & 31.4 \\
\hline Net profits $=$ owners"e rent $(\mathrm{M} €)$ & 22.9 & 23.1 & 16.5 & 1.8 & 0.0 \\
\hline Labor rent $(\mathrm{M} €)$ & 24.3 & 23.8 & 15.1 & 0.0 & -1.9 \\
\hline Owner + labor rent $(\mathrm{M} €)$ & 47.2 & 46.9 & 31.6 & 1.8 & -1.9 \\
\hline
\end{tabular}




\section{Endnotes}

${ }^{1}$ In the nephrops fishery there are, on average, 3.0 crew per boat, with a standard deviation of 1.0 (coefficient of variation of 34\%). The average value of landings per vessel is 336 thousand Euros, with a standard deviation of 172 thousand Euros (coefficient of variation of 51\%).

${ }^{2}$ Hockey stick stock-recruitment relationships have been chosen because they offer a shape closer to the production functions usually used in more theoretically economic models and are more realistic when considering the impact of high effort levels on recruitment. It should be noted that the inflexion point parameters have been arbitrarily chosen from the nephrops stock assessment data because historic recruitments have proven to be robust, and there is no perception of inflexion points on the data. The optimal reference points for this nephrops fishery have shown to be independent of the inflexion points in the stock-recruitment relationships.

${ }^{3}$ Based on insurance value and assuming a 3.65\% interest rate (long-term interest rate 2009 source: Institut National de la Statistique et des Études Économiques - INSEE).

${ }^{4}$ Under normal fishery conditions of inter-annual variations in recruitment, the biomass at sea (B) will not be constant from one year to the next, and consequently the estimated parameters (i.e., revenues, average wages, and rents) are unlikely to be equal to these estimations, but will vary annually around them.

${ }^{5}$ The kink in the revenues versus effort curve is due to the assumed hockey-stick shape of the stock-recruitment relationship curve. 